\title{
Comparison of grazing behaviour, dietary overlap and performance in non-lactating domestic ruminants grazing on marginal heathland areas
}

\author{
R. Celaya ${ }^{\mathrm{a}}$, M. Oliván ${ }^{\mathrm{a}}$, L.M.M. Ferreira ${ }^{\mathrm{b}}$, A. Martínez ${ }^{\mathrm{a}}$, U. García ${ }^{\mathrm{a}}$, K. Osoro ${ }^{\mathrm{a}, *}$ \\ ${ }^{a}$ Servicio Regional de Investigación y Desarrollo Agroalimentario (SERIDA), Apdo. 13, 33300 Villaviciosa, Asturias, Spain

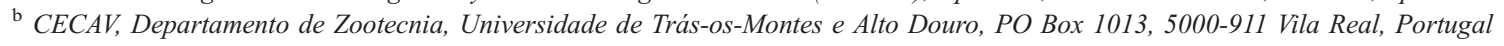

Received 15 May 2006; received in revised form 18 August 2006; accepted 22 August 2006

\begin{abstract}
During the years 2000-2001, 7 non-lactating beef cows, 40 ewes and 40 does were managed in mixed grazing on a natural heathland vegetation plot (22 ha) with $20 \%$ improved pasture (perennial ryegrass) on a hill (1000 m a.s.l.) experimental farm located in the NW of Spain. Samples of faeces and vegetation components were collected monthly to estimate diet selection, using the alkane markers, and diet overlapping level. Animals were weighed monthly to quantify live weight changes and performance of the three livestock species during different periods (spring, summer, autumn, winter) of the grazing season.

The percentage of shrubs in the diet was significantly higher in the small ruminants (ranging between $36 \%$ and $85 \%$ ) than in cows (less than 25\%) in any period. Gorse (Ulex gallii) and heather (Erica spp., Calluna) percentages were always significantly higher in does than in ewes, except in autumn for heather. Herbaceous component (namely grasses) was higher in cattle (75-99\%) than in small ruminants (15-64\%). The lowest mean dietary overlap was found between cattle and goats (50.4\%), with large differences during the grazing season, ranging between $20 \%$ and $70 \%$.

The three animal species increased their live weight in the first grazing period (spring), when the mean sward height on the improved area was higher than $6.0 \mathrm{~cm}$. However, when the sward height was lower than $3.5 \mathrm{~cm}$ (summer-winter), cows lost weight $(-437 \mathrm{~g} /$ day $)$ while ewes and goats were still able to increase their weight ( 29 and $5 \mathrm{~g} /$ day, respectively).

Therefore, it seems that small ruminants, mainly sheep, are more suitable than cattle from the vegetation utilization and animal performance points of view, as cows were unable to maintain live weight when the preferred grass availability decreases. Goats were the species that included the highest proportion of heathland vegetation components in the diet, especially gorse, although their performance was significantly lower than in sheep. In consequence, small ruminant production systems could be more sustainable than cattle. The results indicate that mixed grazing of sheep and goats could be appropriate in these vegetation communities, allowing the development of sustainable systems, in which animal performance and the efficiency of resource use are maximized.
\end{abstract}

(C) 2006 Elsevier B.V. All rights reserved.

Keywords: Cattle; Diet selection; Goat; Gorse; Heather; Sheep

* Corresponding author. Tel.: +34 985890066; fax: +34 985891854 .

E-mail address: kosoro@serida.org (K. Osoro).

\section{Introduction}

Natural vegetation communities have clear differences in their components and level of heterogeneity as a consequence of several factors (soil, climate, etc.) 
including previous management (Milne and Osoro, 1997). In temperate rangeland ecosystems, available biomass quantity is rarely limiting to animal production and factors like digestibility of different plant species, their spatial distribution and seasonal growth probably limit more the nutritional intake (Grant and Maxwell, 1988). Grazing conditions are complex due to variations with time in available quantity, quality and physical structure of the vegetation and environmental conditions (Hodgson, 1986). Significant differences can occur in the intake of plant species with similar digestibility and even between plant parts. The nutritive value (intake, digestibility) of these components also varies between animal species (Hodgson et al., 1991) and even between breeds (Revesado et al., 1994; Osoro et al., 1999b).

Sheep have demonstrated the ability to include high percentages of heather (Erica spp., Calluna vulgaris) shoots in their diet and maintain the live weight and body condition under very low herbage allowance conditions (Osoro et al., 2000b). Likewise, goats are able to include high percentages of gorse in the diet (Clark et al., 1982; Radcliffe, 1986) with significantly higher intake than sheep (Howe et al., 1988). However, the ability of cattle to exhibit diet selection is much lower (Illius and Gordon, 1993) and they have been shown to eat grass components with a higher fiber content than sheep, such as stem-flowers, and require a higher sward height (Wright and Whyte, 1989) than sheep (Osoro et al., 2002). Dumont and Gordon (2003) indicate that sheep and cattle initially select swards that allow them to meet both diet quality and quantity requirements, before using behavioural adjustments such as increasing daily grazing time to maintain diet quality for as long as possible. When total intake decreases below the animal's needs they finally switch to the poor quality alternative. However, Duncan et al. (2003) concluded that selection of foods that offer complementary nutrients, in order to supply the browsing herbivore with a balanced diet, is unlikely to be a major factor increasing the diet breadth. Therefore, given the differences in grazing behaviour of domestic ruminants and because heathlands are covering large hill areas, it is important to understand the grazing behaviour and animal performance of domestic ruminants under the same conditions, and how this changes during the grazing season, for the development of sustainable systems. Earlier studies (Maxwell et al., 1986; Osoro et al., 1999c) on animal performance carried out on heathlands concluded that, due to the low nutritive value of this vegetation type (Hodgson et al., 1991), complimentary areas with preferred plant species are necessary to achieve the economical sustainability of the animal production systems. The availability of some areas with improved pasture could also help to maintain the biodiversity which is important from the environmental point of view, because these areas could act as firebreaks, reducing the risk of big fires which is high under south European conditions and particularly on heathlands (Marquínez et al., 2003), and consequently decreasing the considerable environmental and economical losses produced by fires (MMA, 1997).

The objective of this work was to study, in Southern Europe, the diet selection, overlapping levels and performance of domestic ruminants (cattle, sheep and goats) grazing in marginal heathlands covered by Erica spp. and gorse, including some areas of perennial ryegrass pasture.

\section{Materials and methods}

\subsection{Experimental site}

The experiment was conducted in 2000 and 2001 on one plot of 22.3 ha located at $950-1000 \mathrm{~m}$ a.s.l. at the Carbayal Research Station, Illano, western Asturias, NW Spain $\left(6^{\circ} 53^{\prime} \mathrm{W}, 43^{\circ} 21^{\prime} \mathrm{N}\right)$. According to aerial photographs of the experimental site, the natural vegetation covered almost $80 \%$ of the total plot surface and consisted of mostly short (less than $50 \mathrm{~cm}$ high) heath-gorse shrubland $(71 \%)$, dominated by heather species (Erica umbellata, E. cinerea, C. vulgaris) and gorse (Ulex gallii), a thorny and woody legume. There were also sparse tall heathlands (up to $2 \mathrm{~m}$ high, covering $1.75 \mathrm{ha}$ ) dominated by Erica australis ssp. aragonensis and $E$. arborea, and a small pinewood (0.12 ha) of Scots pine (Pinus sylvestris). The rest of the land comprised 4.6 ha (20.6\%) and was improved during 1999 by soil breakingup and dressing, and subsequent sowing of perennial ryegrass (Lolium perenne cv 'Phoenix'), hybrid ryegrass (L. $x$ hybridum cv 'Dalita') and white clover (Trifolium repens $\mathrm{cv}$ 'Huia'). During the study years the grass sward was well established on the improved area but the contribution of white clover was still almost null.

\subsection{Animals and management}

The grazing season extended from May to December-January of 2000 and 2001. All managed animals were multiparous non-lactating females. During each grazing season seven Asturiana de los Valles beef cows (mean live weight $532 \pm 14.4 \mathrm{~kg} \mathrm{LW}$ ), 40 Gallega and Lacha crossed ewes $(39 \pm 1.2 \mathrm{~kg} \mathrm{LW})$ and 40 Cashmere does $(35 \pm 1.1 \mathrm{~kg} \mathrm{LW})$ were managed together in a mixed herd under continuous grazing to have the same opportunities for diet selection. 


\subsection{Measurements}

\subsubsection{Vegetation}

Grass availability was measured weekly by recording the sward surface height at 100 random points on the improved pasture area using the HFRO swardstick (Barthram, 1986). The botanical composition and height of the short heathlands was estimated in June 2000 by recording the species, plant part, life stage and height at 300 random hits with the HFRO swardstick.

The chemical composition of monthly samples of the main vegetation components (heather, gorse, natural grasses, sown perennial ryegrass) was analysed following the procedures of the Association of Official Analytical Chemists (AOAC, 1990) for ash and nitrogen $(\mathrm{N})$. Crude protein $(\mathrm{CP})$ was calculated as $\mathrm{N} \times 6.25$. Neutral and acid detergent fiber (NDF and ADF) and acid detergent lignin (ADL) were analysed by the methods of Van Soest et al. (1991).

\subsubsection{Diet composition}

The composition of the diet consumed by each species was estimated using the $n$-alkane technique (Dove and Mayes, 1991; Oliván and Osoro, 1997). Faecal grab samples were collected monthly from June to December 2000. Herbage samples of the main vegetal components, leaves or green shoots of heather, gorse, pines, natural grasses and perennial ryegrass, were also collected at the same times. All samples were stored at $-20^{\circ} \mathrm{C}$. After freeze-drying and grinding, the alkanes (from C21 to C36) were extracted using the method of Mayes et al. (1986) modified by Oliván and Osoro (1999) and the contents were determined by gas chromatography. The relative alkane contents of all herbage samples were studied by canonical discriminant analysis (Wilks $\lambda$ ) and six plant groups were initially established that differed in their alkane pattern: E. umbellata-E. cinerea, Calluna, E. australis (including E. arborea), gorse, natural heath grasses (Pseudarrhenatherum longifolium-Agrostis curtisii) and perennial ryegrass. Pines also differed in their alkane pattern but the concentrations were too low compared to the other species. The proportions of the vegetal components in the diet were estimated using a least-squares procedure that minimizes the discrepancies between the observed concentrations of each n-alkane in the faeces (corrected by faecal recoveries calculated in sheep and cattle grazing on mountain pastures; Oliván, 1995) and the estimated proportions of plant components in the diet (Dove and Moore, 1995; Newman et al., 1995). Finally, the obtained individual percentages were pooled into three main groups: heather species (E.
umbellata-E. cinerea + Calluna $+E$. australis), gorse and grasses (perennial ryegrass $+P$. longifolium $-A$. curtisii), because in some samplings the differences in alkane pattern between natural grasses and ryegrass were not enough to discriminate between them, as well as in the case of heather species from Ericaceae family.

\subsubsection{Grazing behaviour}

Besides the diet composition estimates across the grazing season of 2000, the time spent grazing by each animal species on each vegetation type was determined by recording the grazing activity every $15 \mathrm{~min}$ from dawn to dusk on two consecutive days (13 and 14 July 2000).

\subsubsection{Animal performance}

One week after turn-out, animals were weighed and body condition scored (cows: Lowman et al., 1976; sheep: Russel et al., 1969; goats: Russel, 1990). Following this, the animals were weighed and body condition scored monthly until the end of the experimental grazing season. Grazing season was divided into four seasons: spring (May-June), summer (July-midSeptember), autumn (mid-September-November) and winter (December-January).

\subsection{Data analysis}

The overlap in diet composition between animal species was estimated by calculating the Kulcyznski similarity index as $\mathrm{KSI}=100 \sum 2 c_{i} / \sum\left(a_{i}+b_{i}\right)$, where $c_{i}$ is the lesser percentage of $i$ component in the two diets and $\left(a_{i}+b_{i}\right)$ is the sum of the percentages of each plant component in both diets.

Chemical composition data from the different plant species or groups were pooled according to sampling date and analysed by two-way analysis of variance (ANOVA) for the effects of plant component (heather, gorse, natural grasses and perennial ryegrass), season (spring, summer and autumn) and the interaction component $\times$ season. As percentage data of diet composition could not be normalized nor their variances stabilised by transformation, they were analysed for each month using the non-parametric Kruskal-Wallis test to examine the differences between cows, ewes and goats. Live weight changes per initial live weight and per livestock unit (LU, according to the equivalences established by the Common Agricultural Policy between cattle, sheep and goats: 1 cow $=7$ ewes $=7$ goats), and body condition score changes were subjected to ANOVA, including in the model the effects of animal species, year and grazing season. Since the interactions 
between factors were highly significant for all the dependent variables, the raw data matrix was split off according to grazing season and analysed for the effects of animal species, year and their interaction. Tukey's test was used to establish pair-wise differences between livestock species. The effects of grazing season, including the effects of year and their interaction, were studied for each livestock species.

\section{Results}

\subsection{Available vegetation}

\subsubsection{Sward height}

Although some minor differences between years in the mean sward surface height on the improved pasture area occurred during the spring, the general trend in its evolution was similar in both years. The sward height decreased as the grazing season advanced from spring to winter and the strongest decrease occurred between spring $(6.1-7.5 \mathrm{~cm})$ and summer $(3.6-4.2 \mathrm{~cm})$. Later the sward height continued decreasing at a lower rate, from a mean of $2.7 \mathrm{~cm}$ in autumn to $2.2 \mathrm{~cm}$ in winter.

\subsubsection{Botanical composition of heathland area}

The short heathland, which comprised most of the unimproved plot area, was dominated by heather species (frequency percentage of 78.7\%), mainly E. umbellata $(65.7 \%)$ and also E. cinerea $(9.3 \%)$ and C. vulgaris
(3.7\%). Gorse frequency percentage was $9.7 \%$ and other shrubs like Halimium alyssoides and Genistella tridentata accounted for $3.5 \%$ while herbaceous species (mainly coarse grasses such as $P$. longifolium and $A$. curtisii) accounted for only $4.2 \%$ of total contacts. The remaining $4 \%$ was dead matter.

The mean height of the canopy was $30.8 \mathrm{~cm}$, with no differences between heather $(30.9 \mathrm{~cm})$, gorse $(29.8 \mathrm{~cm})$ and other shrubs $(30.7 \mathrm{~cm})$.

\subsubsection{Chemical composition}

The chemical composition of available plant components was significantly different $(P<0.001$, Fig. 1$)$. Cell wall components (NDF) represented the highest fraction in all vegetation components, ranging from a minimum of $41 \%$ (perennial ryegrass in the spring) and a maximum of $76 \%$ (natural grasses in the autumn). Large differences between grasses and woody species were observed in the lignin content, which was $22-31 \%$ of total dry matter (DM) in heather and gorse and 2-5\% in grasses. The perennial ryegrass showed the highest level in crude protein $(13-18 \% \mathrm{CP})$ in all seasons. It should be pointed that gorse presented higher level of $\mathrm{CP}$ than the natural grasses $(9-16 \%$ vs. $7-11 \%$, respectively). Season affected NDF $(P<0.001)$ and ADL $(P<0.05)$ contents, the lowest occurring in spring and the highest in summer-autumn, but not ADF. Protein content decreased as the season advanced in all components $(P<0.001)$, but the decrease occurred at a
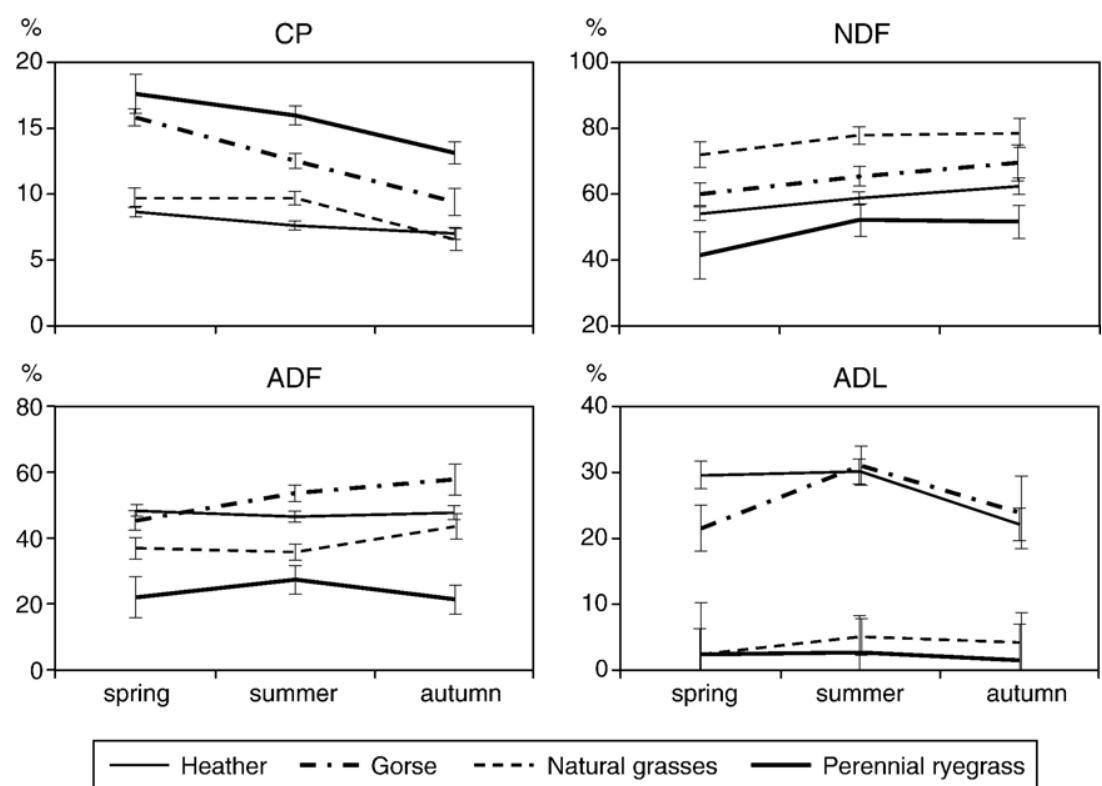

Fig. 1. Chemical composition (least squares means \pm S.E.) of the green shoots and leaves of the main vegetation components according to season. CP: crude protein; NDF: neutral detergent fiber; ADF: acid detergent fiber; ADL: acid detergent lignin. 
higher rate in gorse than in ryegrass and thus the interaction between plant component and season was significant $(P<0.01)$.

\subsection{Grazing behaviour}

\subsubsection{Diet selection}

Significant differences between cows, ewes and does were observed in the composition of the diet during 2000 (Fig. 2). The percentage of woody species (heather and gorse) was significantly $(P<0.001)$ higher in the diet of small ruminants than in cattle. The percentage of those woody species in the diet of cows was not higher than $25 \%$, while it ranged between $36 \%$ and $59 \%$ in ewes and between $49 \%$ and $85 \%$ in does. Cows, in general rejected gorse, achieving maximum percentages in diet in September (12\%) and October $(6 \%)$. There were also differences between the small ruminants.
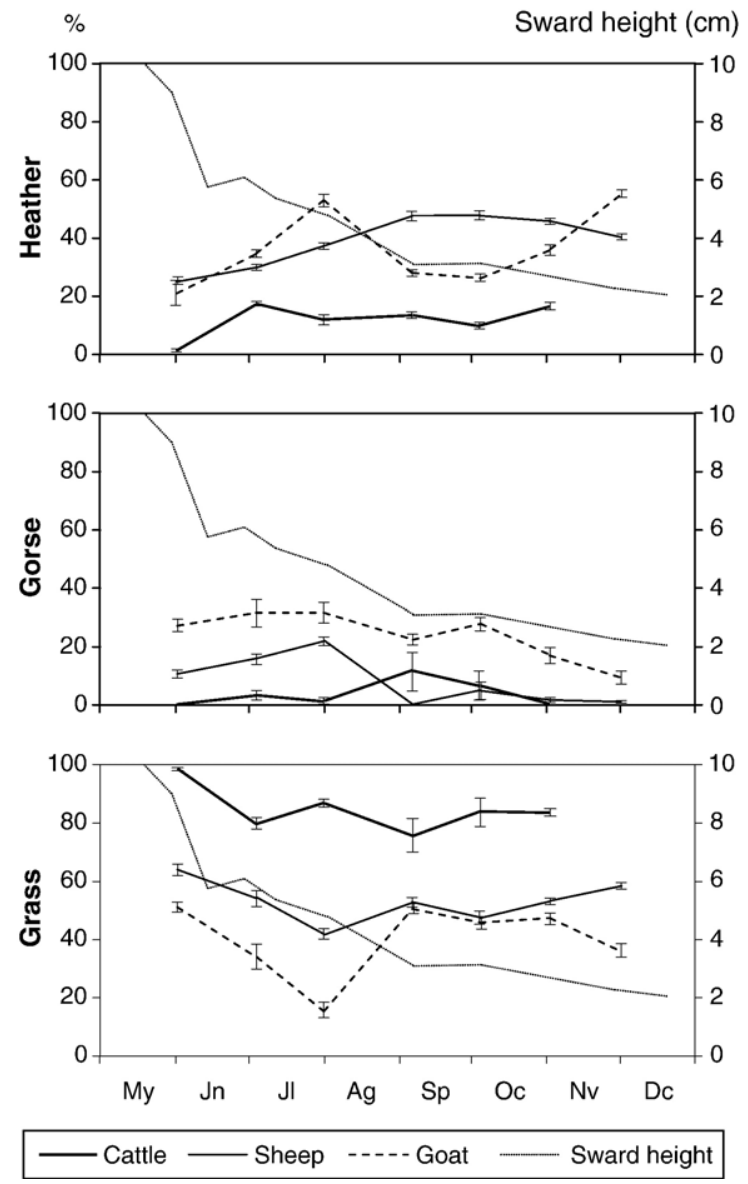

Fig. 2. Diet composition (means of percentage values \pm S.E.) of cattle, sheep and goats grazing in a mixed flock on gorse-heathland with $20 \%$ improved pasture area and sward height in the improved area during the grazing season of 2000 .
Table 1

Degree of overlap (Kulcyznski similarity index) between livestock species in the diet composition grazing on gorse-heathland with $20 \%$ improved pasture

\begin{tabular}{llll}
\hline & Cattle-Sheep & Sheep-Goat & Cattle-Goat \\
\hline June & 65.2 & 72.2 & 47.9 \\
July & 68.7 & 56.5 & 45.0 \\
August & 52.6 & 57.4 & 20.1 \\
September & 65.4 & 55.8 & 63.9 \\
October & 61.8 & 62.0 & 61.7 \\
November & 70.6 & 63.8 & 63.5 \\
December & & 70.6 & \\
Mean & 64.1 & 62.6 & 50.4 \\
\hline
\end{tabular}

Gorse percentage was always significantly $(P<0.05)$ higher in the diet of goats than in ewes. Sheep consumed gorse until August but not beyond then.

The differences between the small ruminants in the percentage of heather intake during the year were less clear than those observed for gorse. No differences were observed at the beginning of the grazing season (June). In July-August it was significantly $(P<0.001)$ higher in the diet of goats than in ewes, but from September to November it was higher in ewes than in goats, compensating for the greater decrease in gorse intake observed in sheep.

The percentage of grasses was significantly higher in the diet of ewes than in goats, except in SeptemberOctober, when there were no significant differences between the two small ruminants. Nevertheless, these percentages of grasses, ranging from $15 \%$ to $64 \%$, were always significantly lower than those found in cows (75-99\%).

\subsubsection{Grazing time}

In July 2000, goats spent more time grazing (644 min/ day) than sheep (550) and cattle (510 min/day). The percentage of grazing time on shrubland was higher in goats $(42 \%$ on short and $19 \%$ on tall heathland) than in ewes (37 and 1\%) and cows (28 and 13\%). Cows and ewes spent similar proportions of grazing time on the improved pasture area (with $5.4 \mathrm{~cm}$ of sward surface height, $60 \%$ of grazing time), though in the case of ewes there were large differences between the two observation days (35-90\%). The cows grazed for more time on tall heathland and less on short heathland than did the ewes. Goats intensively browsed the lowest bushes of Scots pines at specific times ( $2 \%$ of the grazing time), whereas cattle and sheep utilized the pinewood for shelter but not for food.

\subsubsection{Complementarity between animal species}

For the overall grazing season, the greatest overlap (Kulcyznski similarity index) between the three livestock 
species in the selected diet occurred between cattle and sheep $(64.1 \%)$ and the lowest between cattle and goats $(50.4 \%)$, while the index between sheep and goats $(62.6 \%)$ was intermediate but more similar to that between cattle and sheep (Table 1). The lowest overlapping between cattle and goats occurred in the first period of the grazing season, from June to August, achieving a minimum of $21 \%$ in August. From September onwards, as the sward height on the improved area decreased substantially, the indexes between the three animal species were similar, ranging between $60 \%$ and $70 \%$.

According to the grazing times spent on each vegetation type, the similarity indexes obtained in July were $88.2 \%$ for cattle-sheep, 77.4 for cattle-goat and $74.1 \%$ for sheep-goat.

\subsection{Animal performance}

Although main effects of year were not significant on animal performance, there were significant interactions between year and animal species $(P<0.01)$ and between year and season $(P<0.05)$. In the case of sheep, LW changes during spring and winter differed $(P<0.001)$ between both years. However, in goats, year effect was only significant $(P<0.05)$ during autumn whereas in cattle it was not significant.

Cows, ewes and does increased live weight and body condition during the spring grazing in both years, when the available mean sward height in the improved pasture area was over $6.0 \mathrm{~cm}$ (Table 2). During the summer, when the mean sward height decreased to $3.5 \mathrm{~cm}$, cows lost a substantial weight $(-314 \mathrm{~g} /$ day $)$ and these losses increased during the grazing season in autumn $(-459 \mathrm{~g} /$ day $)$ and winter $(-537 \mathrm{~g} /$ day). Under the same conditions of vegetation availability, ewes and goats gained weight, although at a lower rate than in spring. The exceptions were the losses observed in goats during autumn, in both years, when the available sward height was not lower than in winter.

The live weight changes according to the initial body weight were calculated to compare the efficiency, as body weight is considered as one of the main factors affecting intake capacity and total maintenance requirements. It was observed that when the grass allowance was high

Table 2

Mean daily live weight (LW) changes in terms of weight per day and adjusted for initial LW and livestock unit (LU), and body condition changes of cattle, sheep and goats across two seasons when grazing on gorse-heathland with $20 \%$ perennial ryegrass improved pasture (together with the available sward surface height in the improved area)

\begin{tabular}{|c|c|c|c|c|c|c|}
\hline & \multicolumn{4}{|c|}{ Grazing season } & \multirow[t]{2}{*}{ S.E.D. } & \multirow[t]{2}{*}{ Significance } \\
\hline & Spring & Summer & Autumn & Winter & & \\
\hline Sward height (cm) & 6.8 & 3.9 & 2.7 & 2.2 & 0.28 & $* * *$ \\
\hline \multicolumn{7}{|l|}{ LW change (g/day) } \\
\hline Cattle & 835 & -314 & -459 & -537 & 84.9 & $* * *$ \\
\hline Sheep & 79 & 22 & 15 & 50 & 8.2 & $* * *$ \\
\hline Goat & 66 & 14 & -18 & 20 & 11.0 & $* * *$ \\
\hline \multicolumn{7}{|c|}{ LW change (g/day/kg initial LW) } \\
\hline Cattle & 1.61 & $-0.52^{\mathrm{b}}$ & $-0.80^{\mathrm{b}}$ & $-1.02^{\mathrm{c}}$ & 0.164 & $* * *$ \\
\hline Sheep & 2.11 & $0.58^{\mathrm{a}}$ & $0.37^{\mathrm{a}}$ & $1.21^{\mathrm{a}}$ & 0.203 & $* * *$ \\
\hline Goat & 2.07 & $0.45^{\mathrm{a}}$ & $-0.47^{\mathrm{b}}$ & $0.49^{\mathrm{b}}$ & 0.295 & $* * *$ \\
\hline S.E.D. & 0.415 & 0.324 & 0.392 & 0.499 & & \\
\hline Significance & NS & $* *$ & $* * *$ & $* * *$ & & \\
\hline \multicolumn{7}{|c|}{ LW change per LU (g/day/LU) } \\
\hline Cattle & $835^{\mathrm{a}}$ & $-314^{\mathrm{b}}$ & $-459^{\mathrm{c}}$ & $-537^{\mathrm{c}}$ & 84.9 & $* * *$ \\
\hline Sheep & $552^{\mathrm{b}}$ & $156^{\mathrm{a}}$ & $102^{\mathrm{a}}$ & $351^{\mathrm{a}}$ & 57.3 & $* * *$ \\
\hline Goat & $464^{\mathrm{b}}$ & $96^{\mathrm{a}}$ & $-128^{\mathrm{b}}$ & $140^{\mathrm{b}}$ & 76.9 & $* * *$ \\
\hline S.E.D. & 96.6 & 98.0 & 91.7 & 148.4 & & \\
\hline Significance & $* *$ & $* * *$ & $* * *$ & $* * *$ & & \\
\hline \multicolumn{7}{|c|}{ Body condition change } \\
\hline Cattle & $0.41^{\mathrm{a}}$ & $-0.12^{\mathrm{b}}$ & $-0.52^{\mathrm{b}}$ & $-0.17^{\mathrm{b}}$ & 0.124 & $* * *$ \\
\hline Sheep & $0.07^{\mathrm{b}}$ & $0.19^{\mathrm{a}}$ & $-0.17^{\mathrm{a}}$ & $0.25^{\mathrm{a}}$ & 0.067 & $* * *$ \\
\hline Goat & $-0.19^{\mathrm{c}}$ & $0.10^{\mathrm{a}}$ & $-0.12^{\mathrm{a}}$ & $0.03^{\mathrm{b}}$ & 0.059 & $* * *$ \\
\hline S.E.D. & 0.099 & 0.087 & 0.106 & 0.124 & & \\
\hline Significance & $* * *$ & $* *$ & $* * *$ & $* * *$ & & \\
\hline
\end{tabular}

S.E.D. - standard error of the difference.

$* * P<0.01, * * * P<0.001$, NS—not significant $(P>0.05)$

Means with different superscripts within season differ significantly $(P<0.05)$. 
(spring) there were no significant differences between animal species in this parameter. However, in summer there were significant differences between cows $(-0.5 \mathrm{~g} /$ day $/ \mathrm{kg} \mathrm{LW}$ ) and small ruminants (sheep 0.6; goats $0.4 \mathrm{~g} /$ day/kg LW); while cows lost weight, ewes and goats were able to increase their live weight. In autumn, ewes still maintained positive changes, while cows and goats had negative changes, which were not significantly different. At the end of the grazing season, in winter, there were significant differences between the three animal species, being positive in the small ruminants $(1.2 \mathrm{~g} / \mathrm{day} / \mathrm{kg} \mathrm{LW}$ in sheep and $0.5 \mathrm{~g} /$ day $/ \mathrm{kg} \mathrm{LW}$ in goats, $P<0.05$ ) and negative in cows $(-1.0 \mathrm{~g} / \mathrm{day} / \mathrm{kg} \mathrm{LW})$.

Live weight changes per LU were significantly different between cattle, sheep and goats (Table 2). In the first grazing period (May-June), when the mean sward height in the improved area was above $6 \mathrm{~cm}$, cattle live weight gains were significantly $(P<0.01)$ higher than in sheep and goats. However, in the following periods of the grazing season, cattle live weight changes per LU were significantly $(P<0.001)$ lower, losing between 314 and $537 \mathrm{~g} /$ day/LU, while sheep gained weight at a rate higher than $100 \mathrm{~g} /$ day/LU and goats maintained live weight.

\section{Discussion}

\subsection{Grazing behaviour}

The results show that goats selected higher percentages of shrubs and particularly of gorse than sheep or cattle. The higher preference for woody vegetation shown by goats compared to sheep has also been observed in many studies (Morand-Fehr, 1981; Narjisse, 1991; Allan and Holst, 1996). In contrast, ryegrass-clover pastures are utilized more intensively by sheep than by goats (Grant et al., 1984) and the differences between them may increase when they graze in mixed flocks and when they have access to adjacent heathlands (Osoro et al., 2000a). In the same experimental farm, utilizing plots with areas of improved pasture, higher percentages of woody plants were estimated in the diets of goats $(60-70 \%)$ than in sheep diets (20-40\%) (Oliván et al., 1997).

Goats are more susceptible than sheep to parasitism with gastrointestinal nematodes (Pomroy et al., 1986) and thus heather intake by goats could be a self-medication mechanism (Duncan et al., 2003) since heather should not be selected as food from the protein-energy content point of view (see Fig. 1). It has been observed that heather consumption reduces significantly the level of parasite burden in goats (Osoro et al., 2005) which may account for the greater preference for heather shown by goats because of its anthelmintic properties.
The higher gorse percentages in the goat diets compared to sheep diets confirm previous results observed in New Zealand for Ulex europaeus (Clark et al., 1982; Radcliffe, 1985). In pastures with $10-25 \%$ gorse cover Clark et al. (1982) found that the gorse percentage in goat diets was $32 \%$ in summer-autumn, increasing to $90-95 \%$ in winter-spring, while sheep ate only $0-1.5 \%$ of gorse. Radcliffe (1986) obtained 90\% of gorse cuticular fragments in goat faeces in the beginning of spring and $50 \%$ in summer, while the values for sheep were $40-50 \%$ in spring and 5\% in summer. In metabolic pens, Howe et al. (1988) found that the voluntary intake of gorse by goats was 1.8-2.5 times higher than that by sheep in springsummer, while in autumn and winter it was totally rejected by sheep due to the increase in hardness and sharpness of the thorns. This is in agreement with our results, which show that the proportion of gorse in the diet of goats was 1.5 to 2.6 times higher than in sheep diets in spring and summer (June, July, August) while the presence of gorse in the diet selected by ewes was almost negligible (0 to $5 \%$ ) from September to December.

The intensive utilization of pines by goats was also observed in Scottish uplands (Bullock, 1985), where Pinus needles accounted for more than $50 \%$ of the diet of feral goats in February. Although in our study only $2 \%$ of the grazing time of goats was used to browse on pines in July, this value could be much higher in spring when new needles are growing. However, the pinewood area was very small $(0.5 \%$ of the plot area). Indeed, after two grazing years, the pines became completely bare of leaves up to $1.5 \mathrm{~m}$ above ground, suggesting that some protection for the trees could be necessary to develop sustainable silvopastoral systems with goats on pinewoods.

Previous results regarding diet selection by cattle indicate they are grazers and the intake of woody plants such as gorse is more limited than in the small ruminants (Sineiro et al., 1984; Nolan et al., 1996; Aldezabal, 2001). The morphological and physiological adaptations of the different ruminant species to selective feeding behaviour, related to differences in dental and digestive anatomy, have been previously documented (Hofmann, 1989; Illius and Gordon, 1993) and these characteristics have been mainly related to body size (Rook et al., 2004). In our study ewes and cows spent similar grazing times on unimproved area but cattle diets contained a higher percentage of grass than did ewe diets, which indicates a higher selective drive of sheep to incorporate woody species in the diet and a lower ability of cattle to select the green shoots of shrubs (Grant et al., 1987; Oliván and Osoro, 1998), affecting also the bite size and total intake of cows (Hodgson et al., 1991).

Lower dietary overlap or similarity between animal species and higher divergence of feeding strategies means 
that heterogeneous plant resources can be more efficiently utilized because of the lower interspecific competition, thereby increasing animal production (Merrill and Taylor, 1981; Wright and Connolly, 1995). The lower dietary overlap found between cattle and goats than between cattle and sheep or sheep and goats is in agreement with the grazing behaviour of these animal species observed under very different conditions, i.e. in a thornbush savannah pasture (Lechner-Doll et al., 1995) and in the Sahel (Sanon et al., 2005). Under mountain conditions in the Pyrenees (Aldezabal, 2001), similar dietary overlap was observed between sheep and goats and between cattle and goats, with the highest occurring between cattle and sheep, as recorded in this study. The greater overlap between the different species found in the present study is comparable to those under free ranging conditions, especially between cattle and goats. It could be related to the comparatively high stocking rate $(0.9 \mathrm{LU} / \mathrm{ha})$ limiting the grazing behaviour, despite the considerable size of the areas, together with the fewer vegetation components considered.

In a poplar box (Eucalyptus populnea) woodland community of South Australia, the highest dietary overlap in spring was found between cattle and sheep and the lowest between cattle and goats, but at the end of summer and during autumn the lowest overlap was between cattle and sheep (Squires, 1982). Clearly, the overlapping levels may change during the grazing season as the selective behaviour that animals can display depends on the available vegetation (Wright and Connolly, 1995). In natural heterogeneous heath-grassland communities of Scottish Southern Uplands, Bullock (1985) showed that the dietary overlap between hill sheep and feral goats was greatest during late winter-early spring and, to a lesser extent, in the autumn, that is, when the forage quality and quantity were the lowest. In our study, the dietary overlaps generally increased from late summer to winter as the mean sward height of the preferred pasture (ryegrass) in the improved area decreased below $3.5 \mathrm{~cm}$.

\subsection{Animal performance}

The significant effects of the interaction between year and season on animal performance observed in some cases could be attributable to differences in weather and available vegetation conditions together with differences in animal fitness. Year effects were distinct depending on animal species and season, indicating an interaction between resource availability and species ability to adapt.

The performance of cows across the grazing season was lower than that of the small ruminants. Previous studies performed on perennial ryegrass-white clover pastures have shown that cattle intake is significantly reduced under continuous grazing when the mean sward height decreases below $6.0 \mathrm{~cm}$ (Baker et al., 1981; Forbes and Hodgson, 1985) and the effect of sward height on suckler cow live weight changes has been clearly observed (Wright and Whyte, 1989; Osoro et al., 2000c). Therefore it is easy to interpret the live weight changes achieved by cows under different available sward heights in the improved area during the grazing season. Nevertheless, in Agrostis-Festuca natural hill pastures dry cows were able to maintain live weight with only $3.5 \mathrm{~cm}$ sward height, because of the higher bulk density and the larger proportional area covered by these pastures (Osoro et al., 1999a).

Linear responses between sward height and live weight changes have also been observed in cashmere goats across a range of sward height between 3 and $10 \mathrm{~cm}$ (Merchant and Riach, 1994; Osoro and Martínez, 1995). Similarly, a previous survey with nine pairs of sward heights, D.A. Clark, J. Hodgson, A. Illius, T. Hughes, E. Robertson and D. Elston (unpublished, cited by Illius and Gordon, 1993) concluded that goats are the most sensitive to differences in pasture height and sheep the least one. The weight losses suffered by goats in the autumn in both years could indicate a reduction in the availability and changes in the chemical characteristics of key components within the natural vegetation, mainly heather, because its proportion in the diet decreases in September-October, limiting intake and therefore animal performance. Food resources for browsing herbivores are dynamic, varying with season and plant phenology, and learning mechanisms would have to be sufficiently flexible to accommodate the changing quality of available food plants (Duncan et al., 2003). Nevertheless goats maintain their live weight more easily than cattle due to their ability to integrate other vegetation components such as shrubs into the diet, usually rejected by cattle as observed in this study. However, it seems that they also require high quality grass with levels of OMD above 0.68 as indicated by Merchant and Riach (1994) and previously observed by Hughes et al. (1984) and Lu (1988). Therefore these results contradict anecdotal evidence that goats are able to maintain body weight with only fibrous and lignified material.

Sheep have shown the capacity to maintain live weight on very short grass $(2.0 \mathrm{~cm})$ within mosaics of natural vegetation communities (Festuca-Agrostis-Nardus-Calluna), even when Calluna was dominant (Osoro et al., 1999b, 2000b), due to the ability to select Calluna shoots contrary to cattle (Oliván and Osoro, 1998), while on ryegrass-clover pastures sheep maximize the live weight gain at sward heights around 5-6 cm (Osoro et al., 2002). 
Therefore any increase of sward height over that value does not improve live weight gain in sheep in contrast to cattle. This could be an explanation for the higher live weight gains of cattle in the first period of the grazing season (spring) when the mean sward height on the improved area was higher than 6-7 cm. The higher live weight gains in winter than in autumn could be in part related with the end of pregnancy in ewes and does. At the end of the grazing season, the overall live weight changes were clearly more favourable for sheep than for goats. This has also been observed in other experimental conditions where herbaceous cover is significant (Radcliffe et al., 1991; Osoro et al., 2000a).

Despite their improved performance at the beginning, cattle showed poorer performance across the overall grazing season compared to small ruminants. There is a clear interaction between the body weight and the allowance of preferred herbage on live weight changes, being the performance of smaller animals superior under conditions of low availability of nutritive resources (Osoro et al., 1999c; Rook et al., 2004). Furthermore smaller breeds within the same species are in general better adapted to the poorer vegetation conditions, as observed in cattle (Osoro et al., 1999a), sheep (Osoro et al., 1999b), and goats (García et al., 2005).

Under these multispecific grazing conditions with similar livestock units per hectare, cattle production was higher than that of sheep and goats when the sward height in the improved area is maintained over $6.0 \mathrm{~cm}$. However, when that height decreased below $5.0 \mathrm{~cm}$ small ruminant production and mainly that of sheep is much higher than that of cattle. Therefore, wintering feeding period in these marginal mountain areas will be significantly shorter in sheep and goats than in cattle farming.

\section{Conclusion}

Cattle showed a clear preference for grasses, while woody plants accounted for $50-60 \%$ of the diet in sheep and goats, reaching the highest percentages in August. Gorse is intensively selected by goats while its intake by sheep is more affected by the changes in the palatability of this woody species than by grass allowance. Sheep showed the best and cattle the worst performance across the whole year. Goats were the livestock species that best complements with the other species, leading to a more efficient and diverse use of the plant resources on these heterogeneous lands. These results indicate that it is possible to develop sustainable systems with small ruminants on these partially improved heathlands. However, they also highlight the limitations for cattle, as result of the decrease in the availability of improved pasture and the low capacity to include other components in the diet to maintain nutrient intake and live weight.

\section{Acknowledgements}

We gratefully acknowledge the staff of the Carbayal Research Station for their work and care in the management of the animals, often undertaken in difficult conditions, and M.J. Martínez and M. Mocha for their assistance on alkane analysis. We also thank Mariecia Fraser for helpful comments on a draft of the manuscript.

\section{References}

Aldezabal, A., 2001. El sistema de pastoreo del Parque Nacional de Ordesa y Monte Perdido (Pirineo central, Aragón). Interacción entre la vegetación supraforestal y los grandes herbívoros. Consejo de Protección de la Naturaleza de Aragón, Zaragoza, Spain.

Allan, C.J., Holst, P.J., 1996. The ecological role of the goat in maintaining pasture and range. VI International Conference on Goats, vol. 1. International Academic Publishers, Beijing, pp. 427-435.

AOAC, 1990. Official Methods of Analysis, Association of Official Analytical Chemists, 14th edition. Washington DC.

Baker, R.D., Alvarez, F., Le Du, Y.L.P., 1981. The effect of herbage allowance upon the herbage intake and performance of suckler cows and calves. Grass Forage Sci. 36, 189-200.

Barthram, G.T., 1986. Experimental techniques: the HFRO swardstick. The Hill Farming Research Organisation Biennial Report 1984-85. HFRO, Bush Estate, Penicuik, Midlothian, UK, pp. 29-30.

Bullock, D.J., 1985. Annual diets of hill sheep and feral goats in southern Scotland. J. Appl. Ecol. 22, 423-434.

Clark, D.A., Lambert, M.G., Rolston, M.P., Dymock, N., 1982. Diet selection by goats and sheep on hill country. Proc. N.Z. Soc. Anim. Prod. 42, 155-157.

Dove, H., Mayes, R.W., 1991. The use of plant wax alkanes as marker substances in studies of the nutrition of herbivores: a review. Aust. J. Agric. Res. 42, 913-957.

Dove, H., Moore, A.D., 1995. Using a least-squares optimisation procedure to estimate diet composition based on the alkanes of plant cuticular wax. Aust. J. Agric. Res. 46, 1535-1544.

Duncan, A.J., Ginane, C., Gordon, I.J, Ørskov, E.R., 2003. Why do herbivores select mixed diets? In: Mannetje, L.'t, Ramírez-Avilés, L., Sandoval-Castro, C., Ku-Vera, J.C. (Eds.), Matching Herbivore Nutrition to Ecosystems Biodiversity. VI International Symposium on the Nutrition of Herbivores. Universidad Autónoma de Yucatán, Mérida, Mexico, pp. 195-209.

Dumont, B., Gordon, I.J., 2003. Diet selection and intake within sites and across landscapes. In: Mannetje, L.'t, Ramírez-Avilés, L., Sandoval-Castro, C., Ku-Vera, J.C. (Eds.), Matching Herbivore Nutrition to Ecosystems Biodiversity. VI International Symposium on the Nutrition of Herbivores. Universidad Autónoma de Yucatán, Mérida, Mexico, pp. 175-194.

Forbes, T.D.A., Hodgson, J., 1985. Comparative studies of the influence of sward conditions on the ingestive behaviour of cows and sheep. Grass Forage Sci. 40, 69-77.

García, U., Celaya, R., Jáuregui, B.M., Osoro, K., 2005. Efectos de la raza y la carga ganadera sobre la producción de caprinos pastando en brezales-tojales. In: Osoro, K., Argamentería, A., Larraceleta, 
A. (Eds.), Producciones Agroganaderas: Gestión Eficiente y Conservación del Medio Natural. XLV Reunión Científica de la Sociedad Española para el Estudio de los Pastos, Vol. I. SERIDA, Gijón, Asturias, Spain, pp. 207-212.

Grant, S.A., Maxwell, T.J., 1988. Hill vegetation and grazing by domesticated herbivores: the biology and definition of management options. In: Usher, M.B., Thompson, D.B.A. (Eds.), Ecological Change in the Uplands. British Ecological Society Special Publication Series No. 7. Blackwell, Oxford, UK, pp. 201-214.

Grant, S.A., Bolton, G.R., Russel, A.J.F., 1984. The utilization of sown and indigenous plant species by sheep and goats grazing hill pastures. Grass Forage Sci. 39, 361-370.

Grant, S.A., Torvell, L., Smith, H.K., Suckling, D.E., Forbes, T.D.A., Hodgson, J., 1987. Comparative studies of diet selection by sheep and cattle: blanket bog and heather moor. J. Ecol. 75, 947-960.

Hodgson, J., 1986. Grazing behaviour and herbage intake. In: Frame, J. (Ed.), Grazing. BGS Occ. Symp. No. 19, pp. 51-64.

Hodgson, J., Forbes, T.D.A., Armstrong, R.M., Beattie, M.M., Hunter, E.A., 1991. Comparative studies of the ingestive behaviour and herbage intake of sheep and cattle grazing indigenous hill plant communities. J. Appl. Ecol. 28, 205-227.

Hofmann, R.R., 1989. Evolutionary steps of ecophysiological adaptation and diversification of ruminants: comparative view of their digestive system. Oecologia 78, 443-457.

Howe, J.C., Barry, T.N., Popay, A.I., 1988. Voluntary intake and digestion of gorse (Ulex europaeus) by goats and sheep. J. Agric. Sci. 111, 107-114.

Hughes, T.P., Sykes, A.R., Poppi, D.P., 1984. Diet selection of young ruminants in late spring. Proc. N.Z. Soc. Anim. Prod. 44, 109-112.

Illius, A.W., Gordon, I.A., 1993. Diet selection in mammalian herbivores: constraints and tactics. In: Hughes, R.N. (Ed.), Diet Selection: An Interdisciplinary Approach to Foraging Behaviour. Blackwell Scientific Publications, Oxford, UK, pp. 157-181.

Lechner-Doll, M., Hume, I.D., Hofmann, R.R., 1995. Comparison of herbivore forage selection and digestion. In: Journet, M., Grenet, E., Farce, M.-H., Thériez, M., Demarquilly, C. (Eds.), Recent Developments in the Nutrition of Herbivores. INRA Editions, Paris, pp. 231-248.

Lowman, B.G., Scott, N.A., Somerville, S.H., 1976. Condition scoring in suckler cows. East of Scotland College of Agriculture Bulletin, vol. 6 , pp. 1-31.

Lu, C.D., 1988. Grazing behaviour and diet selection of goats. Small Rumin. Res. 1, 205-216.

Marquínez, J., Menéndez, R., Lastra, J., Fernández, E., JiménezAlfaro, B., Wozniak, E., Fernández, S., García, J., García, P., Álvarez, M.A., Lobo, T., Adrados, L., 2003. Riesgos naturales en Asturias. Principado de Asturias, INDUROT, KRK Ediciones, Oviedo, Spain. 133 pp.

Maxwell, T.J., Grant, S.A., Milne, J.A., Sibbald, A.R., 1986. Systems of sheep production on heather moorland. In: O'Toole, M.A. (Ed.), Hill Land Symposium, Galway 1984. An Foras Talúntais, Dublin, pp. 187-211.

Mayes, R.W., Lamb, C.S., Colgrove, P.M., 1986. The use of dosed and herbage $n$-alkanes as markers for the determination of herbage intake. J. Agric. Sci. 107, 161-170.

Merchant, M., Riach, D.J., 1994. The intake and performance of cashmere goats grazing sown swards. Grass Forage Sci. 49, 429-437.

Merrill, L.B., Taylor, C.A., 1981. Diet selection, grazing habits, and the place of goats in range management. In: Gall, C. (Ed.), Goat Production. Academic Press, London, pp. 233-252.

Milne, J.A., Osoro, K., 1997. The role of livestock in habitat management. In: Laker, J.P., Milne, J.A. (Eds.), Livestock Systems in European Rural Development. 1st Conference of the LSIRD network (Nafplio, Greece). MLURI, Aberdeen, UK, pp. 75-80.

MMA, 1997. Incendios forestales en España. Ministerio de Medio Ambiente, Madrid.

Morand-Fehr, P., 1981. Nutrition and feeding of goats: application to temperate climatic conditions. In: Gall, C. (Ed.), Goat Production. Academic Press, London, pp. 193-232.

Narjisse, H., 1991. Feeding behaviour of goats on rangelands. In: Morand-Fehr, P. (Ed.), Goat Nutrition. EAAP Publ., vol. 46. Pudoc, Wageningen, The Netherlands, pp. 13-24.

Newman, J.A., Thompson, W.A., Penning, P.D., Mayes, R.W., 1995. Least-squares estimation of diet composition from $n$-alkanes in herbage and faeces using matrix mathematics. Aust. J. Agric. Res. 46, 793-805.

Nolan, T., Connolly, J., Sall, C., 1996. Dietary agreement between cattle, sheep and goats on semi-arid range under mixed grazing. In: West, N.E. (Ed.), Rangelands in a Sustainable Biosphere. Proceedings of the Fifth International Rangeland Congress. Society for Range Management, Denver, CO, pp. 397-398.

Oliván, M.C., 1995. Pastoreo de comunidades vegetales de montaña por vacuno y ovino. Ph.D. Thesis, Universidad de Oviedo.

Oliván, M., Osoro, K., 1997. Utilización de la técnica de los $n$-alcanos en estudios de ingestión y selección de dieta de los rumiantes en pastoreo: revisión. ITEA 93A (3), 193-208.

Oliván, M., Osoro, K., 1998. Foraging behaviour of grazing ruminants in rangelands. In: Keane, M.G., O'Riordan, E.G. (Eds.), Pasture Ecology and Animal Intake. Teagasc, Meath, Ireland, pp. $110-126$.

Oliván, M., Osoro, K., 1999. Effect of temperature on alkane extraction from faeces and herbage. J. Agric. Sci. 132, 305-312.

Oliván, M., Osoro, K., Celaya, R., 1997. Selección de dieta del ovino y caprino en comunidades de brezal-tojal parcialmente mejoradas. ITEA, VII Jornadas sobre Producción Animal, Vol. Extra 18 (I). AIDA, Zaragoza, Spain, pp. 278-280.

Osoro, K., Martínez, A., 1995. Grazing behaviour and performance of goats and sheep on natural and improved vegetation. In: Laker, J.P., Russel, A.J.F. (Eds.), The Nutrition and Grazing Ecology of Specialty Fibre Producing Animals. European Fine Fibre Network Occ. Publ., vol. 3. MLURI, Aberdeen, UK, pp. 109-125.

Osoro, K., Fernández Prieto, E., Celaya, R., Noval, G., Alonso, L., Castro, P., 1999a. Respuesta productiva de dos razas de ganado vacuno manejadas en dos cubiertas vegetales de montaña. ITEA 95A (2), 188-203.

Osoro, K., Oliván, C., Celaya, R., Martínez, A., 1999b. Effects of genotype on the performance and intake characteristics of sheep grazing contrasting hill vegetation communities. Anim. Sci. 69, 419-426.

Osoro, K., Vassallo, J.M., Celaya, R., Martínez, A., 1999c. Livestock production systems and the vegetation dynamics of Less Favoured Areas (LFAs): developing viable systems to manage seminatural vegetation in temperate LFAs in Spain. In: Laker, J.P., Milne, J.A. (Eds.), Livestock Production in the European Less Favoured Areas. 2nd Conference of the LSIRD network (Dublin). MLURI, Aberdeen, UK, pp. 133-143.

Osoro, K., Celaya, R., Martínez, A., 2000a. The effect of grazing management of sheep and goats on animal performance and vegetation dynamics in partially improved heath-gorse vegetation. In: Rook, A.J., Penning, P.D. (Eds.), Grazing Management. BGS Occ. Symp. No. 34, Devon, UK, pp. 135-140.

Osoro, K., Olivan, M., Celaya, R., Martínez, A., 2000b. The effect of Calluna vulgaris cover on the performance and intake of ewes grazing hill pastures. Grass Forage Sci. 55, 300-308. 
Osoro, K., Ormazabal, J.J., Celaya, R., 2000c. Suckler cows performance during the spring under different sward heights and grazing systems. In: Pullar, D. (Ed.), Beef from Grass and Forage. BGS Occ. Symp. No. 35, pp. 159-163.

Osoro, K., Martínez, A., Celaya, R., 2002. The effect of breed and sward height on sheep performance and production per hectare during the spring and autumn in Northern Spain. Grass Forage Sci. 57, 137-146.

Osoro, K., Benito-Peña, A., Frutos, P., García, U., Ortega-Mora, L.M., Celaya, R., Ferre, I., 2005. The effect of heather supplementation on faecal egg counts of gastrointestinal nematodes and live weight changes in Cashmere and local Celtiberic goats on pasture. Small Rumin. Res. doi:10.1016/j.smallrumres.2005.09.032.

Pomroy, W.E., Lambert, M.G., Betteridge, K., 1986. Comparison of faecal strongylate egg counts of goat and sheep on the same pasture. N. Z. Vet. J. 34, 36-37.

Radcliffe, J.E., 1985. Grazing management of goats and sheep for gorse control. N.Z. J. Exp. Agric. 13, 181-190.

Radcliffe, J.E., 1986. Gorse - a resource for goats? N.Z. J. Exp. Agric. 14, 399-410.

Radcliffe, J.E., Townsend, R.J., Baird, D.B., 1991. Mixed and separate grazing of sheep and goats at two stocking rates. N.Z. J. Agric. Res. 34, 167-176.

Revesado, P.R., Mantecón, A.R., Frutos, P., González, J.S., 1994. Comparative studies of diet selection by Churra and Merino genotypes grazing on a hill shrub community. In: Lawrence, T.L.J., Parker, D.S., Rowlison, P. (Eds.), Livestock Production and Land Use in Hills and Uplands. BSAP Occ. Publ. No. 18, pp. 111-112.

Rook, A.J., Dumont, B., Isselstein, J., Osoro, K., WallisDeVries, M.F., Parente, G., Mills, J., 2004. Matching type of grazing animal to desired biodiversity outcomes - a review. Biol. Conserv. 119, $137-150$.
Russel, A.J.F., 1990. Body condition scoring of goats. Scottish Cashmere Producers Assoc. Newsletter, vol. 10, p. 3.

Russel, AJ.F., Doney, J.M., Gunn, R.G., 1969. Subjective assessment of body fat in live sheep. J. Agric. Sci. 72, 451-454.

Sanon, H.O., Zoungrana-Kabore, C., Ledin, I., 2005. Grazing behaviour and selection of browse species by cattle, sheep and goats on natural pasture in the Sahelian zone of Burkina Faso. In: O'Mara, F.P., Wilkins, R.J., Mannetje, L.'t, Lovett, D.K., Rogers, P.A.M., Boland, T.M. (Eds.), XX International Grassland Congress: Offered papers. Wagenigen Academic Publishers, The Netherlands, p. 539.

Sineiro, F., Osoro, K., Díaz, N., 1984. Bases para la producción e intensificación ganadera en el monte gallego: la utilización de la vegetación espontánea y la siembra y mejora del pasto. Pastos y Forrajes en Alimentación Animal. Actas de la XXII Reunión Científica de la Sociedad Ibérica de Nutrición Animal, Santiago de Compostela, Spain, pp. 195-219.

Squires, V.R., 1982. Dietary overlap between sheep, cattle and goats when grazing in common. J. Range Manag. 35, 116-119.

Van Soest, P.J., Robertson, J.B., Lewis, B.A., 1991. Methods for dietary fiber, neutral detergent fiber, and nonstarch polysaccharides in relation to animal nutrition. J. Dairy Sci. 74, 3583-3597.

Wright, I.A., Connolly, J., 1995. Improved utilization of heterogeneous pastures by mixed species. In: Journet, M., Grenet, E., Farce, M.-H., Thériez, M., Demarquilly, C. (Eds.), Recent Developments in the Nutrition of Herbivores. INRA Editions, Paris, pp. 425-436.

Wright, I.A., Whyte, T.K., 1989. Effects of sward surface height on the performance of continuously stocked spring-calving beef cows and their calves. Grass Forage Sci. 44, 259-266. 